\title{
CONCEPTIONS OF SELF-DETERMINATION IN FOURTH/TENTH-CENTURY MUSLIM THEOLOGY: AL-BĀQILLĀNĪ'S THEORY OF HUMAN ACTS IN ITS HISTORICAL CONTEXT
}

\author{
JAN THIELE \\ CCHS-CSIC, Calle Albasanz 26-28, 28037 Madrid, Spain \\ Email: jan.thiele@cchs.csic.es
}

\begin{abstract}
Man's individual responsibility is a very central notion in Muslim theology. Rational foundations for moral responsibility presuppose, however, that man has in some way control over his actions. It was therefore of central concern to theologians to formulate theories of action that were coherent enough to account for human self-determination. This article examines al-Bāqillānì's reflections on human acts and attempts to contextualise his thought within the discussions of his time. I will briefly review the Mu'tazilites' theory of freedom of action, against which the Ašarite school developed its own position. I will then outline the fundamentals of the opposing standpoint adopted by Abū al-Hasan al-Ašcarī, who proposed to base human self-determination on voluntariness. Finally, I will discuss how al-Bāqillānī drew on and further developed al-Ašarì's ideas. Based on the extant volumes of alBāqillānī's Hidāyat al-mustaršidīn, I argue that he attempts to coherently organise the school's understanding of the famous theory of "acquisition" (kasb) by affirming two fundamental principles: a) that human acts are created by God and b) that there is nevertheless a real correlation between man and his "acquired" acts.
\end{abstract}

Résumé. La responsabilité individuelle de l'homme est une notion centrale en théologie musulmane. Or une justification rationnelle de notre responsabilité morale présuppose que nos actes sont d'une certaine manière sous notre contrôle. Pour les théologiens, il était donc important de formuler une théorie de l'acte humain qui tienne compte de l'autodétermination humaine. Cet article analyse les réflexions d'al-Bāqillānī au sujet de l'acte humain dans le contexte des discussions qui eurent lieu en son temps. Je récapitulerai brièvement la théorie mu'tazilite du libre arbitre, théorie à laquelle s'opposa l'école aš́arite en formulant sa propre position. Ensuite, j'esquisserai les fondements du point de vue d'Abū al-Hasan al-Aš́arī qui proposa de fonder l'autodétermination humaine sur le caractère volontaire de l'acte humain. Finalement, je discuterai comment al-Bāqillānī développe sa théorie en partant des idées d'al-Aš́arī. Sur la base des volumes préservés de la Hidāyat al-mustaršidìn d'al-Bāqillānī, j'argumenterai qu'il envisage de donner plus de cohérence à la célèbre théorie de l' "acquisition" (kasb) en soutenant deux principes: a) l'acte humain est créé par Dieu; b) il existe cependant une corrélation réelle entre l'homme et son acte "acquis". 
It is a widely accepted idea that we are accountable for what we do. In Muslim thinking it is even deeply rooted in a worldview that is shared by the two other Abrahamic religions, where moral accountability is vitally linked to the belief in the Last Judgement. Man's individual responsibility for his actions is consequently regarded as a crucial feature of the relationship between God and His creation. It is however difficult to accept - and even more difficult to plausibly establish individual responsibility for our doings without presupposing that our actions are determined by our very own self. Yet human selfdetermination can be conceived in various forms. The mutakallimūn, that is, theologians who attempted to rationalize and systematically explain their doctrines, also developed different approaches to account for why our acting should be self-determined in some way. ${ }^{1}$

\section{SELF-DETERMINATION AS FREEDOM OF ACTION}

Many of us would intuitively affirm that moral responsibility is related to freedom of action: if we are individually accountable for what we do, we assume that we have control over our actions, and we think that it is up to us to decide whether and how we act. We then presuppose that morality is only possible if freedom of action is true.

Essentially, this was also the prevailing consensus among Mu'tazilite theologians. For them, God's justice was a fundamental pillar of their teaching and they believed that His judgement of man's actions is founded on objective principles and values. Based on these assumptions, they argued that in no way does God create and determine human acts; for if we are accountable for what we do, if we justly deserve reward or punishment, we must be the originators of our acts and have the capacity to behave otherwise than we do. ${ }^{2}$

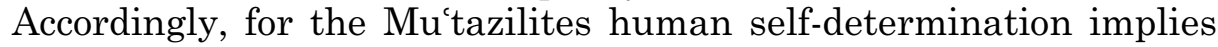
that our acts causally depend upon us, and that the capacity by virtue of which we produce our acts is a power over alternatives: it enables us

${ }^{1}$ As a general introduction to the free will problem, I found Thomas Pink, Free Will. A Very Short Introduction (Oxford, 2004) very inspiring for my reflections on the issue of selfdetermination and responsibility as discussed in medieval kalām.

2 The argument is discussed in detail by Daniel Gimaret, Théories de l'acte humain en théologie musulmane (Paris, 1980), pp. 252-7. With their belief in freedom of action, early Mu'tazilites were opposed to a number of proponents of divine determinism, most prominently represented by Gahm b. Safwān (d. 128/745-6) and his followers, the so-called Gahmiyya. A critical examination of Ğahm's position was still a literary topos in the Mu'tazilites' later writings: see, for example, 'Abd al-Ğabbār al-Hamad̄ān̄i, al-Muginn̄ fī abwāb al-tawhìd wa-al-adl, ed. Muhammad Muștafā Hilmī et al., 14 vols. (Cairo, 19611965), vol. VIIİ, pp. 3, 83; Abū al-Ḥusayn Ahmad Mànekdīm Šešdīw, Šarh al-uṣūl al-h̆amsa, ed. 'Abd al-Karīm 'Uțmān (Cairo, 1384/1965), p. 324; Abū Muhammad al-Ḥasan b. Ạhmad Ibn Mattawayh, Kitā̄b al-Măgmū' fī al-Muhīt bi-al-taklīf, ed. Jean Joseph Houben, Daniel Gimaret and Jan Peters, 3 vols. (Beirut, 1965-1999), vol. I, p. 428. 
to perform two contrary acts and also allows us not to act at all (al-istițā'a [...] hiya qudra 'alayhi wa-'alā diddihi wa-hiya ġayr $m \bar{u} \breve{g} i b a l i$-al-fic $l) .^{3}$

While there was much agreement about man's capability to causally determine his acts on account of his power (qudra), early Mu'tazilite theologians did not necessarily share a unanimous conception of what precisely is meant by human power. ${ }^{4}$ Another question they discussed was whether our acting can be explained on the sole basis of our capability to act or whether our freedom of action - that is, our autonomous choice between various possible options of behaving - depends on something else. ${ }^{5}$

During the fourth/tenth century that primarily concerns us here, the Mu'tazila was no longer an intellectual endeavour of merely independent thinkers, but consisted rather of various well-established sub-schools. The predominant teaching was that of the School of Bassa, which fundamentally relied on doctrines developed, structured and systematised by Abū 'Alī al-Ğubbā'ì (d. 303/915) and his son Abū Hāšim (d. 321/933). The school's theory of the human act is expounded in the works of one of its chief theologians, 'Abd al-Ğabbār al-Hamadānī (d. 415/1025), and further detailed by a number of his students. ${ }^{6}$ In their teaching, human capability to act also fulfils a crucial purpose. By the notion of qudra - or more precisely, by its plural, $q u d a r$ - they referred to entities ( $\left.m a^{c} \bar{a} n \bar{\imath}\right)$ of "power" subsisting in the human body on account of which we are capable of acting. They maintained the fundamental principle, already formulated by the earlier $\mathrm{Mu}$ 'tazilites, that our capability of acting in no way implies any necessity to act. Instead, it empowers us to choose between various alternatives: if we act, it is also our option whether to do the opposite or not to act at all. Any human action is consequently the agent's autonomous decision and therefore determined by his very own self. They argued

${ }^{3}$ Abū al-Ḥasan 'Alī b. Ismāīll al-Ašcarī, Kitāb Maqālāt al-islāmiyȳ̄n wa-ihtilāf al-muṣallīn, ed. Hellmut Ritter, 4th edn (Beirut, 2005), p. 230.

4 For a study on some early conceptions of the qudra see Richard M. Frank, "Remarks on the early development of the kalam", in Atti del III Congresso di Studi Arabi e Islamici (Naples, 1967), pp. 315-29.

5 For example, theologians like Mu'ammar b. 'Abbād al-Sulamī (d. 215/830), al-Ǧāhịiz (d. 255/ 869) and perhaps also Tumāma b. Ašras (d. 213/828-9) suggested, with some nuances, that the occurrence of bodily actions depend in some way on the human will (irāda) (see Gimaret, Théories de l'acte humain, pp. 28-35). The question, whether the Mu'tazilite conception of the human free agency is compatible with some form of determinism, was posed in its most radical form by Dirār b. 'Amr (d. c. 200/815). According to him, human acts have two agents: God who creates and man who "acquires" the act. Most other Mu'tazilites disagreed with this theory to such extent that they even expelled him from the school; see also below.

6 The most comprehensive and reliable analysis of 'Abd al-Ğabbār's understanding of the human act is Richard M. Frank, "The autonomy of the human agent in the teaching of 'Abd al-Ğabbar [sic]", Le Muséon, 92 (1982): 323-55. 
that this is firmly established by our common experience that we act in accordance with our intentions (qașd). ${ }^{7}$

According to the Basran Mu'tazila, our intentional acts do, however, not occur by virtue of our will (irā $d a)$ or motivation $\left(d \bar{a}^{c} \bar{l}\right)$. They even believed that the actual performance of our actions cannot depend on our motivations without violating the idea of our actions being free. They argued that if human actions were not solely grounded in one's capability, but causally depended on something supplemental to one's power - such as motivations -, man could no longer be considered as an autonomous agent. ${ }^{8}$

In fact, the Bassan Mu'tazilites developed a concept that rather appears to contradict the principle outlined above: they posited the existence of motivations that are so strong that the agent cannot but act in a certain way. In the technical language, they framed this idea with the term $i \lg _{\bar{a}}{ }^{\prime}{ }^{9}$ The actual purpose behind the

7 Gimaret, Théories de l'acte humain, pp. 47-8, 56; Frank, "The autonomy of the human agent”, p. 327. In addition to the sources quoted by Gimaret and Frank, see also the relevant passages found in the part on istițāa from 'Abd al-Ğabbār's Mug̈nn, which is missing in the Yemeni recension of the work, but now partially available in the Karaite recension (Nukat al-Kitāb al-Mughn̄i: A Recension of 'Abd al-Jabbār al-Hamadhān̄̄s (d. 415/1025) al-Mughn̄ fī abwāb al-tawhīd wa-l-'adl: Al-Kalām fī l-tawlīd; al-Kalām fī l-istițā́a; al-Kalām fī l-taklīf; al-Kalām fī l-nazar wa-l-ma'ärif. The extant parts introduced and edited by Omar Hamdan and Sabine Schmidtke [Beirut, 2012], pp. 93, 107-11, 113-16).

8 See Frank, "The autonomy of the human agent", p. 327, relying on 'Abd al-Ğabbār, Muginī,

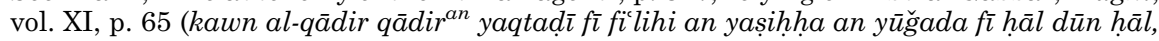

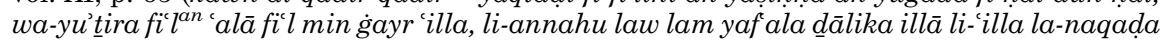

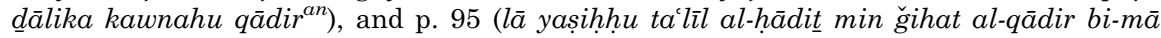
yaqtad̄ ihrăğahu min kawnihi qādir ${ }^{a n}$ ). The question, why the will cannot be the cause ( $m \bar{u} \bar{g} \mathrm{i} i \bar{b}$, 'illa, sabab) for man's actions, is comprehensively discussed by Abū Rašīd Sa'̄id b. Muhammad b. Sā̄ò al-Nīsābūrī, al-Masāì fī al-ȟilāf bayn al-Bașriyȳ̄n wa-al-Bàgdādiyȳ̄n, ed. Ma'n Ziyāda and Riḍ̂ān al-Sayyid (Beirut, 1979), pp. 357-61 and Abū Muhammad al-Ḥasan b. Ahmmad Ibn Mattawayh, al-Tad̄kira fī aḥkām al-ğawāhir wa-al-a'räd, ed. Daniel Gimaret, 2 vols. (Cairo, 2009), vol. II, pp. 560-2. The Bașran Mu'tazilites did, however, not completely deny that one's will and motivations are in some way effective. Rather, they posited that, depending on our intentions, our acts occur "in a specific manner" ('alā wăgh ${ }^{i n}$ ): speech can, for example, have different modalities, and be uttered as a command, a statement or a question. In addition, the Bașran Mu'tazilites believed that our will and motivations may have ethical implications: for example, whenever speech is uttered as a lie, the specific manner in which the act of speaking occurs is the effect of reprehensible intentions and therefore deserves blame. For the Bassran theory of the effectiveness of the will and of motivations see Frank, "The autonomy of the human agent", pp. 331-7 and, in particular with regard to the ethical dimensions of the issue, Sophia Vasalou, Moral Agents and Their Deserts. The Character of Mu'tazilite Ethics (Princeton, 2008) (see especially p. 141 for the modalities of speech).

9 The notion of $i$ lğ $\vec{a}^{\prime}$ was actually interpreted by Gimaret as a form of determinism that is incompatible with human free will (see Daniel Gimaret, "La notion d'impulsion irrésistible' (ilğấ) dans l'éthique mu'tazilite", Journal Asiatique, 259 [1971]: 25-62; Gimaret, Théories de l'acte humain, pp. 48-9, 56-9). Frank, "The autonomy of the human agent" and Wilferd Madelung, "The late Mu'tazila and determinism: the philosophers' trap", in Biancamaria Scarcia Amoretti and Lucia Rostangno (eds.), Yād-Nāma in memoria di Alessandro Bausani, 2 vols. (Rome, 1991), vol. I, pp. 245-57, pp. 245-8, showed that Gimaret misunderstands the Bașran theory. 
Başan theory was, however, that motivations account for why some actions are more likely or more reasonable to expect (awlā) than others. ${ }^{10}$ In other words, motivations are the condition for our doing something deliberately and not just randomly. ${ }^{11}$ The notion of $i \lg ^{2} \vec{a}$ does therefore imply a fairly high degree of likelihood but no necessity. However, our acts do not need to be purposive: according to the Bașran School, they can even lack any rational foundation and consequently be pointless ('abat). ${ }^{12}$

Finally, the Basran Mu'tazilites even posited that our autonomous acts can be entirely non-voluntary: they argued that a sleeping or unconscious man still determines what he does. According to them, we must be in a state of awareness and consciousness whenever we generate motivations. Referring to the sleeper and the unconscious, they could then explain that this is not always the case with human agents, and so conclude that the actual performance of our acts cannot depend on the presence of motivations. ${ }^{13}$ The upshot of this theory was that, according to the Basran School, we can self-determine our behaviour through exercising freedom of action without deliberation. For them, freedom of action is consequently even possible without voluntariness.

The Basran Mu'tazilite theory was not uncontroversial and posed a fundamental question: if freedom of action means that we have various alternatives of action, and if it is true that these alternatives are possible and become actual only by virtue of our power to act, would this not lead to the inconceivable conclusion that two contrary acts occur at the same time? The objection was not only raised by such detractors as Abū al-Ḥasan al-Ašcarī (d. 324/935), the founder of the Ašcarite school, and his follower Abū Bakr al-Bāqillānī (d. 403/ 1013), ${ }^{14}$ but was also identified as a serious problem by a number of

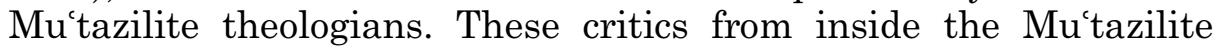
school therefore pointed out that freedom of action actually presupposes voluntariness. For example, Abū al-Qāsim al-Ka'bī al-Balh̄̄ (d. 319/931), who was the head of the Mu'tazila of Baghdad and opposed his contemporary Abū 'Alī al-Gubbā'ì in a number of theological issues, is said to have affirmed that the occurrence of our actions depends on our will in that our will causes our acts to happen. ${ }^{15}$ We have no sources that provide us with further details how he supported his theory. Yet some other Mu'tazilites adopted a similar standpoint, including 'Abd al-Gabbār's student Abū al-Ḥusayn

10 Frank, "The autonomy of the human agent", p. 348.

11 Ibid., pp. 353-4.

12 Ibid., p. 351; Madelung, "Late Mu'tazila and determinism", p. 246.

13 Madelung, "Late Mu'tazila and determinism", p. 246.

14 See Daniel Gimaret, La doctrine d’al-Ash'arī (Paris, 1990), pp. 137, 145 and al-Bāqillānī, Hidāyat al-mustaršidīn, MS Fes, Qarawiyyīn 692, fols. 143b-144a.

15 Abū Rašīd al-Nīsābūrī, al-Masā̉il fī al-ḩilāf, p. 357; Ibn Mattawayh, Taḍkira, vol. II, p. 561. 
al-Bașrī (d. 426/1044) and his later follower Rukn al-Dīn Ibn al-Malāhịimī (d. 536/1141), whose teaching has survived in several important theological works.

As we are told by Ibn al-Malāhimī, Abū al-Husayn posited that acting is impossible without motivation. He supported his theory by referring precisely to the quandary of man's capability equally to produce two contrary acts. Human power, he argued, makes two opposite acts possible to exactly the same degree. This principle was the foundation of the Mu'tazilite belief in freedom of action. If our capability favoured alternative A over alternative B, our freedom of action would be seriously threatened. Yet only one possibility can be actualised, and so Abū al-Husayn concludes that something else is needed for us to exercise our freedom of choice - something that accounts for why either possible action happens. Abū al-Husayn identifies this something with the agent's motivation $\left(d \bar{a}^{c} \bar{\imath}\right)$ for the act of his choice or - in the case of various conflicting motivations - the preponderant motivation (tarağğuh). Against his teacher 'Abd al-Gabbār, he maintained that this is even true for the sleeper and the unaware: although their actions do not follow the same logic as if they were conscious, what they do is still coherent within their actual experience - such as their dreams - and has therefore a purpose. We might forget our motivations once we regain consciousness, we might even act under false assumptions and, as a result, fail to achieve an outcome we actually intended by our actions - in any case, however, the occurrence of our acts depends on the presence of at least one motivation to do what we do, irrespective of how it comes about. ${ }^{16}$

Abū al-Husayn's claim for the need for motivations also affected his conception of the agent $\left(f \bar{a}^{c} i l\right)$. According to the definition found in Tasaffuh al-adilla, the agent causes his acts in a way that is not necessarily effective (al-mu'attir 'ala tarìq al-sihhha). Essentially, this is the $\mathrm{Mu}$ tazilite principle outlined above expressed in other words. What distinguishes Abū al-Husayn's conception is how he explains the nonnecessity of what we do. For him, being not necessarily effective means to make an effect take place according to one's abilities and motivations. However, if we affirm that the occurrence of our actions does not depend on our being motivated to do them, we have to concede the possibility that agents do not cause things to happen in accordance with their motivations. Yet, Abū al-Husayn concludes, this would corrupt the agent's very being. ${ }^{17}$

16 Madelung, "Late Mu'tazila and determinism", pp. 249-52.

17 Abū al-Ḥusayn al-Bașrī, Tașaffuh al-adilla. The extant parts introduced and edited by Wilferd Madelung and Sabine Schmidtke (Wiesbaden, 2006), p. 97: "al-fāil huwa

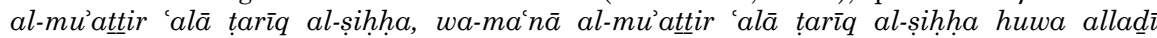

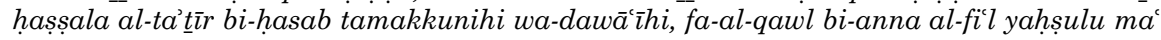


Abū al-Husayn's discussion of the real nature of the agent is found in the context of the question whether God has power (qādir) to do evil. The issue was highly controversial, not only between different theological strands, but also within the Mu'tazilite school itself, since it touched upon the veracity of two fundamental doctrines: the principles that God is almighty and that He is good. Abū al-Husayn's solution to the problem reveals much about his understanding of free agency and the process of decision-making involved. He affirms that God actually has the capability to do evil, thereby doing justice to His all-encompassing power. Nonetheless, he says, it is impossible that God turn His ability to do evil into real action. The reason behind this is His reluctance and lack of motivations to do so (min qibali al-sawārif wa-intif $\bar{a}^{\prime}$ al-dawa $\left.\bar{c} \bar{l}\right){ }^{18}$ This is indeed consistent with Abū al-Husayn's analysis of what it means to be capable: namely that one has the ability not only to act but also to omit the act. ${ }^{19}$

Abu al-Husayn compares the function of motivations with our need to have tools at our disposal allowing us the performance of certain acts: we need a needle to sew and a pen to write. Even if we have the ability to sew and to write, it is not possible for us to do so ( $l \bar{a}$ yahșulu maiahu al-sihh ha) as long as we do not have access to these tools. The fact that we lack these tools, however, does not affect our ability in itself. In line with this idea, Abu al-Husayn stresses the difference between stating that an act is impossible (yastahillu) for somebody and that somebody has no capability to do it. Based on this assumption, he goes on arguing that, similarly, an agent who is capable of performing a certain act depends on his motivations. Yet in no way does this conflict with his actions being self-determined. Abū al-Husayn supports this argument by comparing somebody capable of actions with somebody who is not (' $\bar{a} \breve{g} i z)$. Whoever is reluctant to do that which he is capable of doing will act once his motivations change. In contrast, it is not up to us to cause acts that are beyond our capacities, irrespective of whether we want them to occur or not. ${ }^{20}$

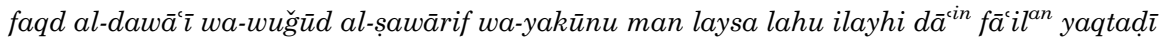

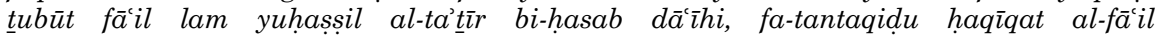
wa-nulabbisuhu bi-man laysa bi-fáci 'il'. Abū al-Husayn goes on arguing that this must even be admitted by his Bașran Mu'tazilite fellows who question his understanding of the

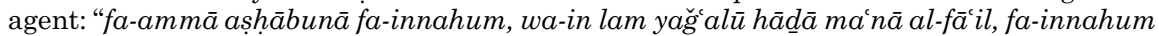

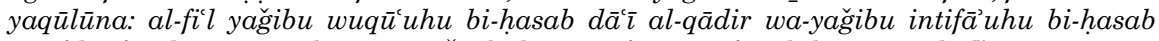

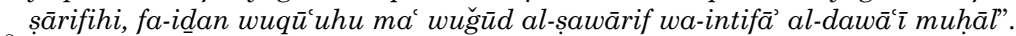

18 Ibid., p. 99.

19 Ibid., p. 97: "al-qādir huwa allad̄i yașihh hu an yaf'ala wa-an lā yaf'ala"; whether one acts or omits the act depends, in accordance with his abovementioned theory, on motivations: "wa-ma'nā dāalika huwa anna fi'lahu yahșulu bi-ḥasab dawā'īhi wa-yağibu intifä̀uhu bi-hasab șawārifihi".

20 Abù al-Ḥusayn al-Bașrī, Taṣaffuh al-adilla, pp. 99-100. 


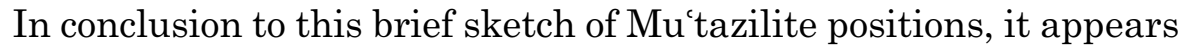
that their theologians agreed on basing human self-determination on freedom of action. Beyond this consensus, however, they proposed different explanations for why our actions should be free. In the fourth/ tenth century, the Basran Mu'tazila represented a trend that identified freedom of action with a power over alternatives. For them, this capacity is sufficient for our actions to be free. Others pointed out that exercising freedom of action also depends on the agent's decisionmaking, something that is not implied by the mere capability to behave in different ways. They argued that free agency always requires intentionality, which accounts for why one of several possible acts happens. Abū al-Husayn al-Bașī followed this logic and therefore considered that our actions depend on motivations without which exercising freedom of action would be impossible.

\section{SELF-DETERMINATION AS VOLUNTARINESS}

\section{Al-Aš 'arī: Moral Responsibility in the Absence of Freedom of Action}

Freedom of action was not only subject to internal debates between theologians who believed in that principle. The idea as such was highly controversial and categorically rejected by many opponents. The Mu'tazilites had, however, advanced a very clear explanation for why we have control over, and consequently are responsible for, our acts. Whoever wanted to question their theory on the same level of rational plausibility would therefore have to put forward an alternative conception of human self-determination. An important position against freedom of action was developed on the basis of the doctrines of Abū al-Hasan al-Ašc arī, a former Mu'tazilite whose teaching laid the foundation for the Aš́arite school of kalām.

The point of departure for al-Aš arî's reasonings on human acts was the doctrine of divine omnipotence. He claimed that God's absolute power is in no way restricted: it encompasses every creation and so all happenings in the world, even those proceeding from others, must depend on Him. Were this not the case, God would have to be conceived as weak and powerless. ${ }^{21}$

Al-Aš arì's understanding of God's omnipotence directly affected his conception of human acts. Since they belong to the temporal world,

${ }^{21}$ See the critical edition and translation of al-Ašsarī’s Kitāb al-Luma, \$§49-53 in Richard J. McCarthy, The Theology of al-Ash'arī. The Arabic text of al-Ash'ar's Kitāb al-Luma and Risālat Istihsān al-Khawd fī 'Tlm al-Kalām, with brief annotated translations, and Appendices containing material pertinent to the study of al-Ash'arī (Beirut, 1953) (in the following referred to as al-Ašarī, Luma). The upshot of this theory was a radical occasionalism: see Dominik Perler and Ulrich Rudolph, Occasionalismus. Theorien der Kausalität im arabisch-islamischen und im europäischen Denken (Göttingen, 2000), pp. 51-6. 
they must also be determined by God: in this sense, al-Aš́arī posits, acts of disobedience are created and foreordained by God. ${ }^{22}$ Similarly, if piety was not created by God and the believer could also disbelieve, God would necessarily be unable to impose His power upon His creation, and this would in turn fundamentally violate the idea of His omnipotence. ${ }^{23}$ Believers and unbelievers therefore act without any possibility for them to act differently: "If the unbeliever were capable of believing," al-Ašcarì says, "he would believe." 24

Al-Aš́arī consequently shared the Bașran Mu'tazilites' view that divine determinism is incompatible with human freedom of action. Departing from a common premise they arrived at diametrically opposed conclusions, however. Since the Mu'tazilites' primary concern was not to violate the principle of God's justice, they assumed that He refrains from exercising His omnipotence in the realm of human acts, thereby giving us full control over how we act. On the other hand, al-Ašarī's main preoccupation was God's omnipotence, and so he argued that there is no creator (hāliq) and no agent $\left(f \bar{a}^{c} i l\right)$ apart from God. ${ }^{25}$ For him, the idea that everything occurs by the divine will means that human free agency cannot be true: according to his view, God alone creates our actions and so al-Ašcari denied that we have the capacity to act otherwise than we actually do. ${ }^{26} \mathrm{He}$ consequently was what we would nowadays call a hard determinist.

By adopting this line of reasoning, al-Ašcarī inevitably faced a fundamental objection. As a former Mu'tazilite he knew all too well that determinism poses a serious threat to morality, since morality involves individual responsibility for our own actions. Therefore, what we are held responsible for must in some way be within our control. But how then could moral responsibility be true if, according to al-Aš́arī, it is not up to us whether or not we act as we do? In order to confirm the validity of determinism, he had to disprove the principal assumption that moral responsibility really depends on our actions being free. He therefore developed an alternative way of understanding human self-determination, a way which differs from its $\mathrm{Mu}$ 'tazilite conception as free and genuine creation of our acts.

22 Al-Ašcarī, Luma', §101; see also Gimaret, Doctrine, pp. 378-9.

23 Al-Ašcarī, Luma', \$\$57-58.

24 Al-Ašcarī, Luma', §135 (all English translations from the Luma are by McCarthy).

25 Al-Ašcarī, Luma', §87; see also Gimaret, Théories de l'acte humain, p. 80; Gimaret, Doctrine, pp. 387-8.

26 Al-Ašcarì radically expresses his determinism in his discussion of the question who are the real "Qadarites" (al-Ǎ̌carī, Luma,$\S \S 120-121$ ), where he concludes: "We affirm that God determines our works and creates them as determined for us, but we do not affirm that of ourselves." 
Appealing to our experience, al-Ašcarì argues that human actions are not all of the same kind. Common sense shows us that there is a difference between such motions as trembling and walking: we feel that our trembling occurs necessarily $\left(i d t i r \bar{a} r^{a n}\right)$, while this is not the case with our walking. ${ }^{27}$ These two motions are, however, not distinguished on account of who produces or initiates the act. Both have a temporal existence: they come into existence after their non-existence and at some point cease to exist. As previously outlined, their creator therefore cannot be other than God in al-Aš́arî's view. But what then distinguishes the "necessary" act from other acts? For al-Ašarī the necessity of our trembling involves our weakness ('ăgz). As a logical corollary, the opposite must be true for all non-necessary actions: they involve our power (qudra or quwwa). Such acts, which, in al-Ašarì's words, "occur on account of a created power" (waqa'a bi-quwwat ${ }^{i n}$ muhdata) are denoted as kasb or iktisāb, usually translated as "acquisition". ${ }^{28}$

Al-Ašarì was not the first to refer to human acts as kasb and $i k t i s \bar{a} b$. Rather, he built on the ideas of earlier thinkers who tended to minimise or even completely deny a human capacity of creation. It is possible that these theologians believed the appropriateness of this terminology was supported by its frequent occurrence in the Qur'ān, where the verbs kasaba, iktasaba and their masdars are used in the meaning of "to do" or "to perform an act". More precisely, these terms are mainly employed when referring to us acting whilst being held accountable for fulfilling or neglecting obligations, duties and prohibitions imposed by God. ${ }^{29}$ In the theological context of describing and analysing human acts, the terms eventually appear to have been introduced into the technical vocabulary by Dirār b. 'Amr (d. c. 200/815). He developed the theory that all our acts are created by God, while our role is restricted to "acquiring" them. This led him to the much-debated conclusion that every human act has two agents, namely God who produces the act and man who "acquires" it. Dirār's theory was modified only a little later by al-Ḥusayn b. Muḥammad al-Nağğāa (d. c. 220/835). Al-Nağğār also posited

27 As Gimaret, Théories de l'acte humain, p. 82, notes, the distinction between necessary and non-necessary acts was not made by such proponents of divine determinism as the Ğahmiyya.

28 Al-Aš ${ }^{\prime}$ arī, Luma', §§92-94; see also the definition in al-Ašcarī, Maqālāt, p. 542: “wa-al-haqq 'ind̄ anna ma'nā al-iktisāb huwa an yaqa'a al-šay' bi-qudra ${ }^{i n}$ muhdața fa-yakuna kasb ${ }^{\text {an }}$ li-man waqa'a bi-qudratihi" and Gimaret, Théories de l'acte humain, pp. 80-1; Gimaret, Doctrine, pp. 131, 391.

29 See, for example Q 2:286, 3:161 or 24:11; there were even more economic interpretations of kasaba in such verses as Q 2:79 (see M. Schwarz, "Acquisition' (kasb) in early Kalām”, in Samuel M. Stern, Albert Hourani and Vivian Brown [eds.], Islamic Philosophy and the Classical Tradition. Essays presented by his friends and pupils to Richard Walzer on his 70. birthday [Oxford, 1972], pp. 355-87, pp. 361-2). 
that we "acquire" acts created by God, but for him only man himself is the agent of any such actions. Ibn Kullāb (d. c. 240/854), who, in many respects, was a precursor of al-Ašcarì's teaching, also used the term $k a s b$, but we do not have a clear account of precisely how he employed it. ${ }^{30}$

Al-Ašarī took these reflections as points of departure for his own theory. Being concerned to do justice to God as the all-encompassing creator, the terminology derived from the root $k-s-b$ helped him to speak about human acts and, at the same time, to avoid asserting that these acts are brought into existence by man himself, as implied by such verbs as facala or - the even more controversial - halaqa. In addition, the Qur'ānic connotation of kasb/iktisāb introduced the very central aspect of morality. This semantic nuance was crucial for al-Aš arī's theory, since for him, human beings are only responsible for "acquired" acts and not for "necessary" acts. ${ }^{31}$

In order to properly understand al-Aš arī's position, it still needs to be explained on what basis he holds us accountable for such acts, if it is not us who actually originate them. Although al-Ašc arī's extant writings do not directly answer this question, a passage from his Luma helps us to make sense of his line of reasoning. In the following quotation, al-Aš́arī analyses the relation between our actions and our will:

[W] hen an unwilled act of a man takes place, it must be the result of unmindfulness, or weakness and feebleness, or failure to attain his desire. [...] That is so because the reason which enforces the man's weakness and failure to attain his desire, when he knows what proceeds from him but does not will it, is that what he wills does not take place and that he did not will what does take place. For if what he wills takes place, he is not overtaken by weakness and feebleness; but if it does not take place, he is overtaken by feebleness and failure to attain his desire, because it proceeds from him while he knows it but does not will it. ${ }^{32}$

The discussed scenario of somebody failing to do what he actually wants describes a pattern which is echoed in al-Ašcarì's portrayal of the "necessary" act. In this context, "necessity" (darüra) is defined as:

that to which the thing is constrained and compelled and forced, and from which it can find no way to get free or to escape, even though it strive to be freed from it and want (arāda!) to escape from it and exhaust its endeavors to do so. ${ }^{33}$

30 Schwarz, “'Acquisition' (kasb) in early Kalām”, pp. 358-68. See also Josef van Ess, Theologie und Gesellschaft im 2. und 3. Jahrhundert Hidschra. Eine Geschichte des religiösen Denkens im frühen Islam, 6 vols. (Berlin/New York, 1991-1997), vol. III, pp. 45-8 (for Dirār b. 'Amr), vol. IV, pp. 149-50 (for al-Nağğār) and vol. IV, p. 195 (for Ibn Kullāb).

31 Śchwarz, “Acquisition' (kasb) in early Kalām”, pp. 373-7.

32 Al-Ašcarī, Lumá, §59.

33 Al-Ašc arī, Luma', §92. 
It is true that in the above-quoted passages al-Ašcarī does not refer in consistent terms to the "weakness" or "feebleness" that accounts for why we may act against our willing and wanting. Whereas in the first case he appeals to our "weakness" ( $\left.d a^{c} f\right)$ and "feebleness" (wahn) to explain why in some cases we consciously do things that oppose our will, he denotes the "weakness" involved in "necessary" actions by the term 'ăgz. Nonetheless, he obviously refers to the same circumstances of acting: despite terminological inconsistency, one could hardly consider how the act discussed in the first quotation should be perceived by its agent as a non-necessary act. Yet it is precisely on the basis of the agent's individual experience of acting under compulsion that al-Ašcarī establishes the "necessary" act as opposed to "acquired" acts.

What al-Aš́arī here suggests against the Mu'tazilites' conception of self-determination as freedom looks consequently very much like basing morality and responsibility on voluntariness: whenever performing an "acquired" act, we act as morally responsible agents, because we do things according to our willing and wanting. On the other hand, we cannot blame people for actions they do on account of their weakness and against their willing and wanting them to happen. The Bassran Mu'tazilite principle that freedom does not presuppose voluntariness is thereby turned upside down: for al-Ašcarì we can act voluntarily without having freedom of action - i.e. without any possibility to act otherwise than we do.

The fundamental assumption that our actions can still be voluntary even if we cannot omit them might be far from straightforward and even be in apparent contradiction to our common thinking. That both ideas can be harmonised is, however, well illustrated by a famous example that helped the 17th-century philosopher John Locke to demonstrate that voluntariness and necessity are not opposed to each other. That example concerns a man who stays in a room of his own volition, while unbeknownst to him the door is locked. Although he is not able to do otherwise and leave the room, he is still acting according to his volition. Therefore, his staying in the room is, in this sense, a self-determined act exercised through voluntariness. ${ }^{34}$

If we interpret al-Ašarīs accounting for moral responsibility along this line of reasoning, we still face a number of unresolved questions. Most of these issues turn around the precise conception and function of our "power" (qudra) within his theory. Since for al-Aš arī all human

34 The basing of moral responsibility on voluntariness in the absence of freedom is also found in Western philosophy, a belief prominently represented by the sixteenth-century reformer John Calvin; see Thomas Pink, "Power and moral responsibility", Philosophical Explorations, 12 (2009): 127-49, pp. 139-43 and, in a more popular form, Pink, Free Will, pp. 73-9. 
acts are God's creation, there is no causal connection but only conjunction between the qudra and the "acquired" act. But how do we then have to understand his definition of "acquired" acts as "that which occurs on account of a created power" (ma waqa'a bi-qudrat ${ }^{i n}$ $m u h d a \underline{t a} a$ )? What, in particular, is the meaning of the particle bi-, considering al-Ašarī's denial that man is in any way capable of causing his own acts? If we perform "acquired" acts whenever our will conforms with how we act, what is al-Ašcarì's ontological conception of the will - and why does he rely on the concept of qudra at all? ${ }^{35}$

We cannot be sure whether or not al-Aš arī ever addressed these questions. Even though they are not discussed in his extant writings, we have to bear in mind that the vast majority of his extensive work is missing while only a handful of treatises have survived. What we can reconstruct on the basis of some few original writings and the additional later accounts of his theology is therefore not a coherent theory. However, later representatives of al-Ašarī's school took his thoughts as their point of departure for further analysis of human acts. I want to focus in the following on a third-generation Ašcarite, Abū Bakr al-Bāqillānī, who can rightly be described as one of the major protagonists of the school's scholastic consolidation.

\section{Al-Bāqillānī: The Effectiveness of Human Power}

Essentially, two extant works of al-Bāqillānī's theological writings provide us with substantial information as to how he drew on and further developed al-Ašcarì's theory of "acquired" acts. The first of these two works, the Kitāb al-Tamhīd, bears witness to al-Bāqillānī's attempt to systematically compile and coherently organise the teachings of his predecessors. ${ }^{36}$ It has been convincingly argued that this book was in fact one of al-Bāqillānī's early works, possibly written around 360/970.37 Our second source, which must have been one of al-Bāqillānī's last works, is his magnum opus in theology, Hidāyat

${ }^{35}$ Essentially, these questions were already raised by Gimaret, Doctrine, pp. 391-6, who concludes that they can even not be satisfactorily answered on the basis of later Ašarite accounts - such as Ibn Fūrak's Muğarrad maqālāt al-Ašcarī, our most important secondhand source on al-Ašcarî’s theology.

${ }^{36}$ See Heidrun Eichner, The Post-Avicennian Philosophical Tradition and Islamic Orthodoxy. Philosophical and Theological summae in Context (Unpublished "Habilitation"-Thesis, Martin-Luther-Universität Halle-Wittenberg, 2009), pp. 160-4; through analysing the literary structure of the work, she concludes that "the $K$. al-Tamhid marks a transgression between a comprehensive presentation of doxographical material and attempts to develop a theory of the systematical coherence of the doctrines expounded" (p. 160).

${ }^{37}$ Daniel Gimaret, "La théorie des ahwâl d'Abû Hâšim al-Ğubbầî̀ d'après des sources aš́arites", Journal Asiatique, 258 (1970): 47-86, pp. 76-7; Gimaret, Théories de l'acte humain, p. 94-5; Daniel Gimaret, "Un extrait de la Hidāya d’Abū Bakr al-Bāqillānī: le Kitāb at-tawallud, réfutation de la thèse mu'tazilite de la génération des actes", Bulletin d'études orientales, 58 (2009): 259-313, p. 259 (with further references). 
al-mustaršidinn. ${ }^{38}$ Within the four fragments that have survived from this multi-volume summa, we find substantial parts of the discussions related to human actions. ${ }^{39}$ Al-Bāqillānì's solutions of specific theological questions were not consistent throughout his life. It is in particular in the Hidāya that he looked for alternative approaches to such issues and thereby revised some of his earlier positions. ${ }^{40}$ Our particular interest in the Hidāya consists here in the fact that al-Bāqillānì addresses a number of those abovementioned questions left unresolved in al-Ašcarì's theory of human action. Yet the incompleteness of the text and damages to the manuscripts ${ }^{41}$ sometimes make it difficult to reconstruct his position in its full details.

Al-Aš'arī's starting point for explaining our responsibility for certain acts is also central to al-Bāqillānī's approach: he adopts the distinction between "necessary" and "acquired" acts. Originally, the Hidāya contained a definition of the concept of "acquisition", which is however lost and only referred to as occurring in a previous passage. ${ }^{42}$ Anyway, the Tamhi $\bar{d}$ also includes a definition that draws on al-Aš́arî's theory whilst introducing a new idea. According to this definition, "acquisitions" are acts, which, in contrast to "necessary" acts, are performed by agents who possess a power in the substrate of and simultaneously with the act (tasarruf fi al-ficl bi-qudrat ${ }^{i n}$ tuqārinuhu $f \bar{\imath}$ al-mahall). ${ }^{43}$ This is merely a reformulation of al-Ašcarì's view. But what is particular about al-Bāqillānī’s approach is that, apparently for the first time in the Ašcarite literature, he ties the notion of "acquisition" to the agent's choice (ihtiyār) and also once to the agent's intention or purpose $(q a s ̦ d) .{ }^{44} \mathrm{Al}$-Bāqillānī's claim that power over "acquired" acts involves the agent's choice of this

38 The relative chronology can be established by two citations of the Tamhīd found in the Hidāya (see Gimaret, "Un extrait de la Hidāya d'Abū Bakr al-Bāqillān̄̄”, p. 265 and Sabine Schmidtke, "Early Ašcarite theology. Abū Bakr al-Bāqillān̄̄ (d. 403/1013) and his Hidāyat al-mustaršidīn", Bulletin d'études orientales, 60 [2011]: 39-71, p. 43).

39 For the manuscripts and their content see Gimaret, "Un extrait de la Hidāya d'Abū Bakr al-Bāqillān̄̄" and Schmidtke, "Early Aš́arite theology". On the topic of the human act, al-Bāqillān̄ also wrote a Kitāb Ahkām tașarruf al-ibād, quoted in the Hidāya (MS Fes, fol. $112 \mathrm{~b}=$ Gimaret, "Un extrait de la Hidàya d'Abū Bakr al-Bāqillān̄̄", p. 286, §67).

40 A famous example is al-Bāqillān̄̄s adaption of the Mu'tazilite notion of hāal: after having completely rejected the concept in the Tamhīd, al-Bāqillānī eventually came to use it in the Hidāya; for further details see below.

41 In particular, the beginning and the end of MS Fes are affected by damages to the paper.

42 See al-Bāqillānī, Hidāya, MS Fes, fol. 9b: "[...] šarahnnāhu min qablu fī hadd al-kasb".

43 Abū Bakr Muḥammad Ibn al-Ṭayyib al-Bāqillānī, Kitāb al-Tamì̄̄, ed. Richard J. McCarthy (Beirut, 1957), p. 307, §527; see also the definition in Abū Bakr Muhammad Ibn al-Ṭayyib al-Bāqillān̄̄, al-Taqrīb wa-al-iršād (al-ṣag̀ìr), ed. 'Abd al-Hạāìd b. 'Alī Abū Zunayd, 3 vols. (Beirut, 1993-1998), vol. I, p. 233: "mā waqa'a maqdūr ${ }^{a \dot{n}}$ lahu bi-qudrat muhdatat ${ }^{i n}$, wa-laysat qudrat ${ }^{\text {an }}$ 'alā ihdātihi wa-inšàihi”.

44 See Gimaret, Théories de l'acte humain, p. 87, referring to al-Bāqillānī, Tamhīd, pp. 308, $\S 527$ and $286, \S 486$. Even before, the notion of $i k t i s \bar{a} b$ was apparently tied to the agent's choice (ihtiyār) by the Imāmī theologian Hišām b. al-Ḥakam (d. 179/795-6) (Schwarz, " 'Acquisition' (kasb) in early Kalām”, p. 370). 
particular act is also repeated in the Hidāya as part of his extensive refutation of the so-called theory of tawallud, that is the idea that human beings have capability of acting outside their own body through causal chains:

[T] he "acquisition" is distinguished from the "necessary" [act] by virtue of the fact that power over [the act] subsists [in the agent] and that he in whom [the power] subsists is capable of [acting] and choosing it. ${ }^{45}$

Al-Ašcarî’s original assumption that our moral accountability does not depend on freedom of action being true is consequently followed up by al-Bāqillānī. Suppose I choose to walk from A to B and act according to my choice. Although I am not the producer of this act in the Aš́arite view, I still have decided to move intentionally, unlike when shivering from fever, about which I have no choice at all. Al-Bāqillānī's preference for the notion of choice might look like only a minor and arbitrary modification, unless we consider some further explanations, which help us to understand why he avoided the notion of the will that al-Ašcari had still used in the Lumac.

Al-Bāqillānī belonged to a generation of Ašcarites that made significant contributions to the consolidation of the school's teaching. ${ }^{46}$ The permanent challenge by rival systems of thought certainly raised the theologians' concern to achieve greater consistency in their doctrines. One result of the ongoing attempts at systematisation was that, against al-Aš arî’s original suggestion, the conceptualisation of the will was not - or no longer - compatible with the notion of kasb. Accordingly, al-Bāqillānī rejects - first in the Tamhīd and later in the Hidaya - the notion that whether or not we "acquire" an act

45 Al-Bāqillānī, Hidāya, MS Fes, fol. 112b (edited as part of Gimaret, "Un extrait de la Hidāya d'Abū Bakr al-Bāqillān̄̄”, p. 286, §67): “al-kasb innamā yufāriqu al-darūrī bi-wuğūd al-qudra 'alayhi wa-kawn man wuğida bihi qādir an 'alayhi wa-muhtāran lahu”.

46 Al-Bāqillānì's central role in the history of Aš arism was highlighted as early as at the beginnings of Ašcarite studies in the nineteenth century: since then, scholars repeatedly relied on Ibn Haldūn's (d. 808/1406) famous account on the evolution of Aš́arite kalām, which is found in his Muqaddima (see, for example, Martin Schreiner, "Zur Geschichte des Aścaritenthums", in Actes du $8^{e}$ Congrès International des Orientalistes [Leiden, 1893], pp. 79-117, pp. 81-3). Ibn Haldūn attributes to al-Bāqillānī a number of revisions of earlier Aš́arite doctrines. As we know today, the examples provided by Ibn Haldūn - al-Bāqillānī's teaching on atoms, void and the fact that accidents need a substrate - are in fact positions that were already held by al-Aš́arī himself; see Richard J. McCarthy's article "al-Bākillānī" in $E I^{2}$, and for more detailed discussions Gimaret, Doctrine, pp. 35-63 (on atoms), pp. 63-5 (on void), pp. 75-97 (on accidents) as well as Richard M. Frank, "The Ašcarite ontology: I primary entities", Arabic Sciences and Philosophy, 9 (1999): 163-231; in addition, Ayman Shihadeh, "The argument from ignorance and its critics in medieval Arabic thought", Arabic Sciences and Philosophy, 23 (2013): 171-220, pp. 217-20 showed that Ibn Haldūn's presentation of al-Bāqillānı̄'s teaching on rational proofs is imprecise. Surprisingly, Ibn Haldūn is, however, silent on such original positions as al-Bāqillānī's abovementioned adaption of the concept of $h \bar{a} l$ or the developments of the theory of $k a s b$ discussed in this article. 
actually depends on our will being involved. ${ }^{47}$ One explanation for this claim is al-Bāqillānì's view that the will itself is an "acquired" act. ${ }^{48}$ Little imagination is therefore needed to anticipate the almost inescapable objection that if the "acquisition" of an act of will requires another act of will, this would lead to the unacceptable claim of an infinite chain of acts of will.

But al-Bāqillānī makes an additional point, which is based on his reflections on how the human will relates to reality. Our will (and similarly aversion), he argues, does not necessarily relate to the possible or to possible "acquisitions" ( $m \bar{a}$ yașihhu hudūtuhu aw hudūtuhu wa-iktisābuhu) but in some cases to the impossible (mā yastahillu). Suppose somebody wants to perform - or, to keep the Ašcarite terminology, to "acquire" - an impossible act. His will is then based on his conviction (ictiqād) and assumption (zann) that the actually impossible act is possible. This conviction or assumption is, however, not knowledge ('ilm), since real knowledge only encompasses that which is actually true (sahi $\left.\bar{l} h^{a n} h \bar{a}\left[d i \underline{t}^{a n}\right]\right)$. In contrast, convictions and assumptions can be wrong and consequently extend to the impossible. Indeed, the upshot of these premises is that whenever we know that something is impossible, we cannot will it (istahāla

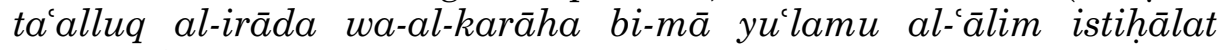
hudutitihi). But as long as we do not know, but only assume that an act is possible, the act we want to perform is by definition not an object of knowledge ( $m a^{c} l \bar{u} m$ ), and so may consequently be impossible. ${ }^{49}$

Accordingly, al-Bāqillānī denies that our will accounts for how, or even necessitates that, we "acquire" acts (laysat bi-illa li-wuğūdihi $w a-l \bar{a}$ sabab $m \bar{u} \bar{g} \mathrm{i} i b l a h u)$. And because we sometimes fail to exercise our will, he says, there can only be one possible conclusion: the nonoccurrence of an act we want at a given moment can only be explained by a lack of power ('adam al-fi'l ma' al-irāda dalīl 'alā anna man lam yaqa' minhu gayr qādir 'alayhi). ${ }^{50}$

As previously outlined, al-Bāqillānì's recourse to the notion of "power" (qudra) in the context of "acquisitions" was, in itself, not a new idea: al-Ašcarī had already used it to distinguish between "necessary" and "acquired" acts. However, al-Ašcarī's conception of human power remained obscure in various respects. Before I turn my attention to al-Bāqillānī's approach to these unresolved questions, it is worth pointing out first that his conception of the human qudra is built on the major tenets established by the school's founder.

47 See al-Bāqillānī, Tamhīd, p. 286, §486 and al-Bāqillān̄̄, Hidāya, MS Fes, fol. 112b (edited in Gimaret, "Un extrait de la Hidāya d'Abū Bakr al-Bāqillān̄”, p. 286, §67).

48 See al-Bāqillān̄i, Hidāya, MS Fes, fol. 9b.

49 See al-Bāqillānī, Hidāya, MS Fes, fols. 10b-11b.

50 See al-Bāqillānī, Hidāyat al-mustaršidīn, MS Tashkent, al-Biruni Institute of Oriental Studies, Academy of Sciences of the Republic of Uzbekistan, 3296, fol. 6a. 
There are essentially three features of human power by which al-Ašcari sharply distinguished his conception from that of the Mu'tazilites. For al-Ašarì's opponents, man's power must already exist before he acts. Otherwise, they argued, we would act out of necessity and not contingently as they claimed. Al-Ašcarī, in contrast, posited that man has power only simultaneously with his act. While the $\mathrm{Mu}$ 'tazilite principle of freedom of action implied that man's power enables him to two contrary acts or to an act and omission, al-Aš́arī denied this doctrine. For him, human power only relates to

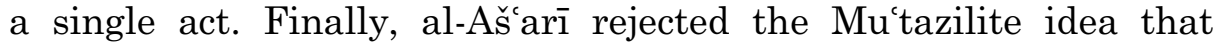
human power can continue to exist for several instants of time.

Al-Bāqillānī agrees with al-Aš́arī on each of these issues. He even presents many identical arguments to support these claims, first in the Tamhìd and later in the Hidāya. Against the Mu'tazilite thesis that man must be capable of action before he acts, al-Bāqillānī replies that we then have to concede the possibility of actions being done by incapables (' $\bar{a} \check{g} i z)$ who lost their capacities at the moment they act. ${ }^{51}$ If man had simultaneous power over two alternative acts, this would not only pose the logical problem that two opposed acts would necessarily happen at the same time: both contraries would even occur in the same substrate, which, al-Bāqillānī says, is inconceivable. ${ }^{52}$ Finally, he rejects the continued existence $\left(b a q \bar{a}^{\prime}\right)$ of human power on the basis of the Aš arites' categorical denial that accidents $\left(a^{c} r \bar{a} d\right)$ exist longer than one instant of time. ${ }^{53}$

For a better understanding of how al-Bāqillānī attempted to solve some of the above-mentioned questions raised by al-Aš́arì's theory, we have to ask about the function of human power within the framework of his theory of acts. While al-Bāqillānī's Tamhīd does not offer any further reflections on this question, he seeks to address it in the Hidāya. In a passage of this text, which defends the claim that man's power and his action must be simultaneous, al-Bāqillānī posits that the occurrence of acts depends on the existence of power ( $y a h t \bar{a} \bar{g} \mathrm{~g} u$ al-fi'l fī wuqū'ihi wa-wuğüdihi ilā wuğūd al-qudra 'alayhi). This dependence is described by al-Bāqillānī as being analogous to the dependence between a predicate $(\mathrm{hukm})$ and the ground ('illa) on account of which a predication is made or said to be true. In contrast to the relation between 'illa and hukm, however, it is not man's power

51 Al-Bāqillān̄̄, Hidāya, MS Fes, fol. 143a; al-Bāqillānī, Tamhīd, p. 287, §488; for al-Ašcarì’s original argument see Gimaret, Doctrine, pp. 137-8, based on al-Ašcarī, Luma

52 Al-Bāqillān̄i, Hidāya, MS Fes, fol. 143b-144a; for al-Aš‘arī’s identical objection see Gimaret, Doctrine, pp. 137, 145 based on al-Aš́arì, Luma', §§ 126-127.

53 It was argued that, otherwise, accidents would never cease to exist and their contraries could not possibly come into existence (al-Bāqillānī, Hidāya, MS Fes, fol. 145a); also see for al-Ašcarīs view Gimaret, Doctrine, pp. 90, 133; Frank, “The Ašcarite ontology”, p. 197. 
which necessitates his acts (al-qudra ġayr mūğiba; lā yahtāăg [al-ficl] ilayhi $\left[=i l \bar{a}\right.$ wuğūd al-qudra] li-yūğada). ${ }^{54}$

But if our actions do not occur by virtue of our power, how can it be true that man's acts depend on his power? Al-Bāqillānì's answer to this apparent contradiction was to claim that denying that our power causes the existence of acts does not prevent it from affecting our acting in some other way. Accordingly, he argued that the human power of "acquisition" actually has an effect ( $t a^{\prime} \underline{t} \bar{r} r$ ). While al-Ašcarī himself does not even use the term $t a^{\prime} t \bar{t} r$ in relation to man's power in his extant writings, some later Ašcarites report that he completely rejected the idea of any such effectiveness. ${ }^{55}$ According to al-Šahrastānī (d. 548/1153), this position was only later revised by al-Bāqillānī. He is said to have formulated the theory that acts are qualified by a property or attribute whenever their performance is conjoined by the existence of power in the agent. ${ }^{56}$ Al-Bāqillānī's conceptualisation of the effectiveness of human power was, however, more complex, if not ambivalent. In the Hidāya he suggests three approaches to understanding how power affects our acting. One of them proposes that the agent himself is affected, while the two others attempt to examine the correlation between agents and their acts.

Al-Bāqillānī first takes into consideration how agents themselves are affected by their qudra. He departs from the notorious scenario on which the distinction between "necessary" and all other acts is based. As we have seen, this distinction was commonly used by Aš arites to prove that whenever we act necessarily, we do not possess the power by virtue of which we describe agents of "acquired" acts as powerful ( $q \bar{a}$ dir). Now al-Bāqillānī developed a different conception than al-Ašcarì of that which is expressed, or referred to, by such affirmations as "he is powerful". For al-Aš arī, this predication only refers to the existence of the qudra, that is an entity conceptualised as an accident ('arad) that inheres in the agent. In contrast, al-Bāqillānī says in the Hidāya that such predications as "being powerful" refer to a real feature - a hă $l$ ("state") in the technical language - of the subject described as powerful. For him, the $h \bar{a} l$ of "being powerful" (kawnuhu $q \bar{a} d i r^{a n}$ ) and the existence of power (qudra) are not identical but

${ }^{54}$ See al-Bāqillānī, Hidāya, MS Tashkent, fol. 1b.

${ }^{55}$ Gimaret, Théories de l'acte humain, pp. 88-90. This account by al-Šahrastānī, which was also later adopted by Fahr al-Dīn al-Rāzī, al-Āmidī and others, is, however, challenged by Ibn Fūrak in his Muğarrad maqālāt al-Ǎšarī, ed. Daniel Gimaret (Beirut, 1987), pp. 923; see Gimaret, Doctrine, p. 392.

56 Gimaret, Théories de l'acte humain, pp. 92-3 (relying on Muhammad b. 'Abd al-Karīm al-Šahrastān̄̄, al-Milal wa-al-niḥal=Books of Religious and Philosophical Sects, ed. William Cureton, 2 vols. [London, 1842-1846], vol. I, pp. 69-70 and Muhammad b. 'Abd al-Karīm al-Šahrastān̄̄, Nihāyat al-aqdām fī 'ilm al-kalām, ed. Alfred Guillaume [London, 1934], pp. 72-6, 87); see also below. 
reciprocally entail each other: the existence of power is evidenced (madlūl) by the $h \bar{a} l$, which, in turn, is grounded in, and becomes actual by virtue of, the existence of power. ${ }^{57}$ It is precisely in this sense that al-Bāqillānī describes the effectiveness of human power in relation to the agent himself: whenever man performs an acquired act, the qudra is the ground for a $h \bar{a} l$ or attribute (sifa) of "being powerful" and thus for a qualification that distinguishes him from

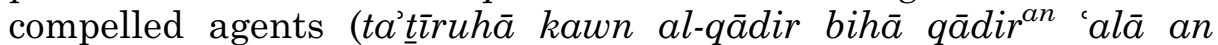
yataharraka wa-yaskuna wa-yurīda wa-yanzura wa-ya'lima wa-yafkira. fa-yakūnu bi-kawnihi qādir 'an 'alā hāl man lahu hādihi

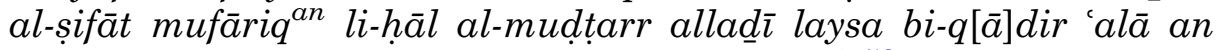
yataharraka wa-yaskuna wa-yurìda wa-ya'lima). ${ }^{58}$

This conception of the effectiveness of human power, however, does not account for why acts should be considered as ours. The proponents of human freedom of action, in contrast, provided a rather simple solution to this question: for them, our acts only occur by virtue of our power. They consequently argued that we are responsible for our acts because their occurrence is causally connected to us. From his

57 The notion of $h \bar{a} l$ was introduced into the conceptual framework of kalām by Abū Hāšim al-Ğubbā'̄ . Al-Bāqillānī's position on this concept was not consistent. In the Tamhīd, he devotes a whole chapter to refuting it (al-Bāqillānī, Tamhīd, pp. 200-3, §§339-344). Later, however, in the Hidāya, he borrowed and adapted the concept, primarily to prove the existence of entitative attributes in God. In accordance with Abū Hāšim, al-Bāqillān̄ assigned to the $h \bar{a} l$ a reality that cannot be described by the dichotomy of existence and nonexistence (al-Bāqillānī, Hidāyat al-mustaršid̄̄n, MS St Petersburg, The Institute of Oriental Manuscripts of the Russian Academy of Sciences, C329, fol. 35a). His idea of the reciprocal correlation between a $h \bar{a} l$ and its entitative ground is well summarised in the following passage: "the knower's being knowing entails the existence of entitative knowledge (kawn

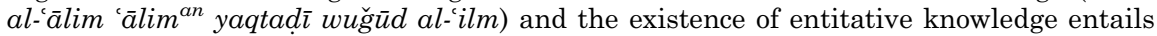
his being knowing. [...] The existence of entitative knowledge entails the knower's being knowing in the sense that it is the ground ('illa) that accounts for his being knowing [...]. The knower's being knowing does not necessitate entitative knowledge (lā yaqtad̄ wuğ $\bar{u} b$ al-'ilm), because 'his being knowing' refers to a $h \bar{a} l$ of [the knower], and the general consensus is that the ahwāl do not necessitate entities. [However], it is possible to say that the knower's being knowing entails the existence of entitative knowledge in the sense of the 'evidence for that which is evidenced' ('alā ma'nā iqtid $\bar{a}$ ' al-dalāla li-al-madlū $l$ ), since the existence of knowledge is evidenced by [the knower's being knowing] [...].” (al-Bāqillānī, Hidāya, MS St Petersburg, fol. 62b). I will be further exploring al-Bāqillānī's notion of hạ $\bar{l}$ in a forthcoming publication; for some preliminary observations based on al-Bāqillān̄̄'s Hidāya see Jan Thiele, "Abū Hāshim al-Jubbā'ì's (d. 321/933) theory of 'states' (ahwāl) and its adaption by Ash'arite theologians", in Sabine Schmidtke (ed.), The Oxford Handbook of Islamic Theology (Oxford, 2016), pp. 364-83, pp. 377-82.

58 See al-Bāqillānī, Hidāya, MS Fes, fol. 152b; see also fol. 146b where al-Bāqillānī describes the entity of power as the ground ('illa) for the agent's "being powerful”: "hãdihi 'illa [...]

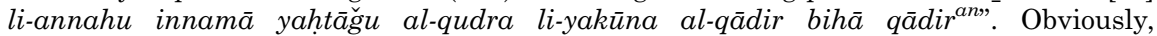
al-Bāqillānī posited that compelled agents are qualified by a $h \bar{a} l$ of being "powerless" ( $\bar{a} \breve{g} i z$ ), which is opposed (mutada $\bar{a} d d a$ ) to that of the "powerful". This can be deduced from a passage from the section on attributes (Kitāb al-Sifāt) in the Hidāya, where a detractor argues that only entities ( $\underline{d} a w \bar{a} t)$ can be opposed to each other; in this context, he refers to the opposition between the $h \bar{a} l$ of the "powerful" and the "powerless" that al-Bāqillānī affirms; see al-Bāqillānī, Hidāya, MS St Petersburg, fol. 99a-b. 
Aš́arite perspective, al-Bāqillānī found this explanation unacceptable, since for him it violates the claim of God being the all-encompassing Creator. He therefore rejects the notion that our acts are brought into existence by virtue of our power, however not at the cost of denying any relation (táclluq) between our power and our acts.

The concept of taclluq was frequently used in the terminology of kalām. Both Aš́arite and Mu'tazilite theologians applied the notion of correlation to a number of properties or attributes (sifa $\bar{t}$ ) and also to accidents $\left(a^{c} r \bar{a} d\right)$ in which these properties are grounded. ${ }^{59}$ More precisely, the term was employed whenever the subject qualified by such a property is in some way related to another object or a target: assumptions or statements are made about something, and we perceive objects distinct from ourselves by sensual perception. The kalām theologians therefore reasoned that our making assumptions or statements and our perception imply a correlation with something else. As explained by al-Bāqillānī, the extent of that which relates to a particular property completely depends on the property in question. For example, an assumption (zann) is not based on sufficient evidence for being qualified as knowledge ('ilm). While real knowledge implies that that which is known is true, assumptions can be wrong. As a logical corollary, that which we assume to be true may in fact not be real, and so al-Bāqillānī concludes that that which relates to assumptions is much more wide-ranging (awsa, $a^{c} a \mathrm{~mm}$ ) than that which can be known: unlike knowledge, that necessarily relates to the known as

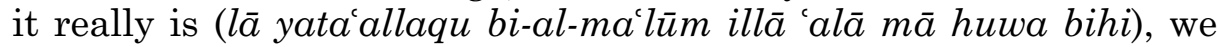
may also assume that something is other than it really is ('al $\bar{a} m \bar{a}$ huwa bihi tārat ${ }^{a n}$ wa-'alā mā laysa bihi uhrō). ${ }^{60}$ The range of possible objects of perception is, in turn, even more restricted, since we can only perceive specific things that actually exist (al-idrāk fa-innahu lā yata'allaqu illā bi-käin mawğ $\bar{u} d) .{ }^{61}$

With regard to human power, al-Bāqillānī claims that, in principle, our qudra may relate to whatever can be created and "acquired" (tata'allaqu bi-mā yașihhhu an yuhdata wa-yașihhu [an] yuktasaba), further specifying that this excludes the eternally and the continuous-

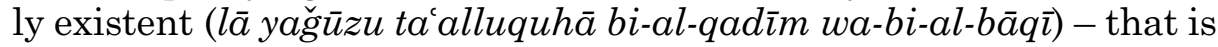

59 Al-Bāqillānī refers to these properties as al-ṣifāt allatī lahā tåalluq (al-Bāqillānī, Hidāya, MS Fes, fol. 7a); in the section on attributes (Kitāb al-Ṣifāt) of the Hidāya, he also refers to knowledge, power and the will as examples for a class of accidents that relate to something else (ğins mā lahu táalluq min al-a'rād ka-al-‘ulūm wa-al-qudar wa-al-irādāt; see al-Bāqillānī, Hidāya, MS St Petersburg, fol. 135b). For a comprehensive Bașran Mu'tazilite account of correlations established by accidents see Ibn Mattawayh, Tadkira, vol. I, pp. 6-8.

60 See al-Bāqillānī, Hidāya, MS Fes, fol. 7a-8b.

61 See al-Bāqillānī, Hidāya, MS Fes, fol. 11b. 
God and atoms - or two contraries (al-diddayn) at the same time. Therefore, any considerations about how power affects our acting merely applies to actions of our limbs or mental acts ( $a f^{\prime} \bar{a} l$ al-ğawārih wa-al-qulüb), including motion, rest, acts of will and knowledge. In order to do justice to man's inability to create what he "acquires", al-Bāqillānī adds the remark that the performance of such acts involves two powers, each of which relates to a given act in different respects (yata'allaqu bihi qudratān 'alā wağhayn muhtalifayn): God's power accounts for its creation (ihtirā') and man's power for its "acquisition". 62

According to al-Bāqillānī, man's power must be suitable (șāliḥa) for a specific act, and there can only be a correlation on condition that we have power when our act comes into existence. ${ }^{63}$ However, whenever these conditions are fulfilled, our power - or our "being powerful" necessarily relates to the "acquired" act. Otherwise, al-Bāqillānī argues, acts performed by a powerful, a sick person and a powerless were alike. ${ }^{64}$ As for the question about the precise nature of the relationship between man's power and his acquired acts, al-Bāqillānī provides two possible solutions.

In the first of his two approaches, al-Bāqillānī argues that positing the effectiveness ( $t a^{\top} \underline{t} \bar{r}$ ) of human power does not necessarily imply the meaning that man's "acquired" acts are created and exist (ihdātuhu wa-wuğ $\bar{u} d u h u$ ) by virtue of his power. Nor does it mean that the coming into existence of such acts entails that they come to have an attribute by virtue of man's power (tağaddud [MS: tăg dì d] sifa tatba'u hudūtahu wa-wuğūdahu șāra al-muktasab 'alayhā bi-al-qudra). Rather, al-Bāqillānī illustrates his view by drawing a parallel with the relation between knowledge and the known or sensual perception and the object perceived. Both have a real and knowable correlation with a specific object, even though knowledge and perception do not cause their objects to exist or to possess an attribute. Al-Bāqillānī concludes that it is precisely in this sense that the relation between man's power and his "acquired" act should be understood

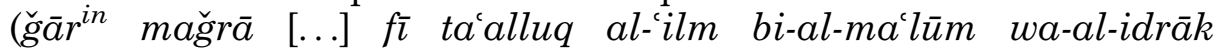
bi-al-mudrak fī annahu ta'alluq tāobit ma'lūm mahșūs fa-in lam yakun ma'nāhu wa-ta'tīiruhu fī ğa'l al-ma'lūm wa-al-mudrak

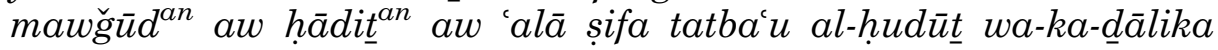

62 See al-Bāqillānī, Hidāya, MS Fes, fol. 9a-b.

63 Al-Bāqillān̄̄, Hidāya, MS Tashkent, fol. 15b: "fa-in kānat [al-istițāa] șāliha li-[al-fïl] fī hāal

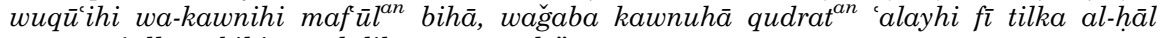
wa-muta'allaqa bihi, wa-d̄ālika mā naqūlu".

64 Al-Bāqillān̄̄, Hidāya, MS Fes, fol. 114a (= Gimaret, "Un extrait de la Hidāya d'Abū Bakr al-Bāqillān̄̄”, p. 286, §71): “wa-law lam yakun li-kawnihi kasb ${ }^{a n}$ ta'alluq bi-kawn

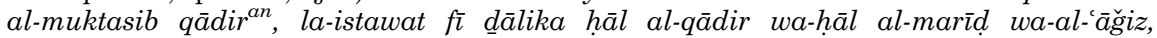
wa-d̄ālika mimmā qad 'ulima buṭ̂̄̄nuhu fa-tabata mā qulnāhu”. 
al-qudra muta'alliqa bi-al-maqdūr ta'alluq ma'lūm mahșūṣ wa-in lam yakun ma'nāhu wa-ta'tīiruhu ğa'l al-maqdūr mawğ $\bar{u} d^{a n}$ aw

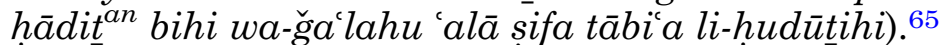

Yet al-Bāqillānī's first response to the question how acts created by God are related to their human agents does not resolve the more fundamental issue, namely that of our individual moral responsibility. For the Mu'tazilites, we are accountable for what we do and fail to do because the creation and omission of our acts is determined by our very own selves. Accordingly, they argued that the Ašcarite theory of action makes nonsense of morality. How could it be true that we are rightly and fairly praised and blamed for acts if it is not us who create them? And would not God oblige man beyond his capacities and unjustly reward and punish him for what is actually divinely created? 66

To answer this problem, al-Bāqillānī develops a different understanding of what is specifically subject to moral assessment in our acting. His solution is found in his second approach to conceptualising how man's created power affects, and relates to, his acts. Surprisingly, al-Bāqillānī appears, however, to contradict himself when he addresses the question of our individual moral responsibility: despite his previous denial, he now affirms that the human act comes to have an attribute on account of man's created power. As he further explains, it is to this very attribute that God's command, prohibition, promise, threat, praise, blame, compensation and punishment relate

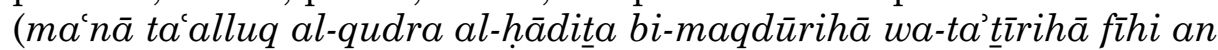
yașīra [MS: tașīra] bihā 'alā sifa tābica li-hudūtihi wa-bi-tilka al-șifa yata'allaqu al-amr wa-al-nahy wa-al-wacd wa-al-wa'ìd wa-al-madh wa-al-damm wa-al-tawāb wa-al-iq $\bar{a} b)$. ${ }^{67}$

Al-Bāqillānì's line of argumentation is consequently based on the assumption that individual moral responsibility does not mean that man is accountable for the very existence of his acts. He thereby neutralizes a central argument of the proponents of freedom of action. In affirming that "acquired" acts come to have an attribute by virtue of man's power, al-Bāqillānī then provides a second major component in his attempt to reconcile moral responsibility with divine determinism. Appealing to this attribute, al-Bāqillānī could argue that a real feature of "acquired" acts is determined by man's very own self although he does not create them. In line with the argument that

65 Al-Bāqillānī, Hidāya, MS Fes, fol. 153a-b. Al-Ǧuwaynī later formulated a similar position in his Iršād (ed. Muhammad Yūsuf Mūsā and 'Alī 'Abd al-Mun'im 'Abd al-Hamīd [Cairo, 1369/1950], p. 210); he denies, however, that the correlation between qudra and maqdūr implies any effectiveness of man's power on his "acquired" acts (see Gimaret, Théories de l'acte humain, pp. 121-2).

66 The argument is further developed in Gimaret, Théories de l'acte humain, pp. 252-5.

67 Al-Bāqillānī, Hidāya, MS Fes, fol. 154a. 
compelled agents have no power, he could furthermore argue that it is precisely this attribute that distinguishes "acquired" from "necessary" acts. ${ }^{68}$

The idea that acquired acts come to have an attribute by the effect of human power was already discussed in Gimaret's seminal Théories de l'acte humain en théologie musulmane. The earliest evidence for this thesis he was able to consult was an account found in Abü Ga'far al-Simnānī's (d. 444/1052) al-Bayān 'an ușūl al-īmān. In this work al-Simnānī posits that whenever we "acquire" actions, their coming into being is accompanied by an attribute that relates to man's power and will. This attribute is subject to God's command and prohibition, praise and blame. Al-Simnānī was al-Bāqillānī's student, but he nowhere credits these assumptions to his teacher. Gimaret could only suppose on the basis of later reports that this was also al-Bāqillānī's position. ${ }^{69}$ These later sources include most importantly the works of al-Šahrastānī. He attributes to al-Bāqillānī the thesis that God creates our acts - say an act of moving - and leaves us control over the precise modalities (wuğūh) of our acting. That is, whenever we "acquire" a movement created by God, we determine by our own self whether it is rising, sitting down, praying, etc. ${ }^{70}$ Yet the passages from the Hidaya examined above confirm what Gimaret already suspected: that al-Šahrastānī does not reproduce al-Bāqillānì's original theory but rather adapts it to his own understanding of human agency.

The chapter on human "power of acquisition", which is found in the Hidāya, does not end with a conclusion. This opens some room for speculation as to which of the three solutions al-Bāqillānī ultimately considered the appropriate answer to the problem of how our power affects our acting. Even if al-Bāqillānī's first answer does not necessarily conflict with the two others, the second and the third answer appear to be inconsistent, if not contradictory, and therefore demand some further clarification. A possible explanation of the problem could be that al-Bāqillānī only distinguished the three levels of effectiveness

68 Al-Bāqillānī, Hidāya, MS Fes, fol. 142b: "[al-`abd] innamā yaḥtā̌̆ ilāa [al-qudra] li-yașīra al-kasb bihā ‘alā șifa tufāriqu șifat al-id̦tirār."

69 Gimaret, Théories de l'acte humain, pp. 101-3. Recently, the Bayān was published and the relevant passage is found in Abū Ğa far Muhammad b. Aḥmad b. Muhammad al-Simnānī, al-Bayān 'an uṣūl al-ìmān wa-al-kašf 'an tamwīhāt ahl al-ṭig̀yān, ed. ‘Abd al-'Azīz b. Rašīd al-Ayyūb (Kuwait, 1435/2014), pp. 243-4.

70 Al-Šhrastānī also denotes the "modalities" of man's acting as "a hāl that is supplemental to existence" ( $h \bar{a} l z \bar{a} i d a^{\prime}$ 'alā al-wuğ $\bar{u} d$ ) and "rational points of view" (ictibārāt 'aqliyya). In his accounts it is not always clear whether al-Šahrastānī provides a paraphrase or his own interpretation of al-Bāqillānīs teaching. The relevant texts (al-Š́ahrastānī, Milal, vol. I, pp. 97-8 and al-Šahrastān̄i, Nihāya, pp. 73-5) were analysed by Harry Austryn Wolfson, The Philosophy of Kalam (Harvard, 1976), pp. 692-3, Gimaret, Théories de l'acte humain, pp. 104-15 (including French translations of the texts) and Ahmed Alami, "L'ašcarisme face à la théorie des modes", Philosophie, 77 (2003): 45-68, pp. 52-7. 
of human power from a logical point of view: the first level would then concern the agent himself in that he acts intentionally by virtue of his power of "acquisition", the second level of effectiveness would connect him with his act, and the third would affect the act inasmuch as it is distinguished by some property from "necessary" acts.

A fragment of a sentence, which, due to manuscript damage, is decontextualized, seems to favour a different interpretation, however: it rather suggests that, according to al-Bāqillānī, either of these three modalities excludes the two others. ${ }^{71}$ It seems, however, that the discussion of the three options is not meant to test out alternative hypotheses, of which only one can be confirmed while the two others have to be rejected categorically. Instead, al-Bāqillānī apparently supposes that, depending on some circumstances, human power is effective in any of the described ways. This understanding is confirmed by a passage from the section on God's attributes (Kitāb al-Sifa $\bar{t}$ ) contained in the Hidāya, which explains possible meanings of the effectiveness of power (qudra):

Power (al-qudra) either relates [a] to the creation of an entity (ma'nā) or [b] to the "acquisition" [of this entity] in that [power] relates to the entity whilst it exists or [c] in that [the entity] comes to have an attribute that accompanies its coming into existence. ${ }^{72}$

From al-Bāqillānī's perspective, only God has power to create things (and, consequently, His power alone can relate to their creation); therefore, only the second and the third modality described in this quotation are relevant to human acts, as is also underlined by the use of the term "acquisition". These two modalities can be easily identified with the second and the third explanation of the effectiveness of human power as discussed in the chapter on human "acquisitions". Since they are presented here as real alternatives, al-Bāqillānī must have assumed that human power can be effective in more than one way. This largely answers the question how to understand al-Bāqillānì's contradictory affirmations - that human power relates to an act without causing it to have an attribute (second answer) and that "acquired" acts come to have an attribute by virtue of man's power (third answer): both scenarios are possible options, which we can only assume occur under different circumstances. In the extant parts of the Hidāya, I cannot find, however, any solution

71 See al-Bāqillānī, Hidāya, MS Fes, fol. 152b: “[...] qudratuhu bi-ihdātihihi wağaba an yuqāla

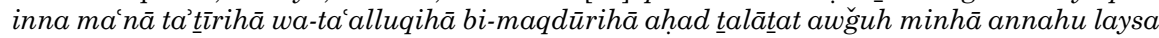

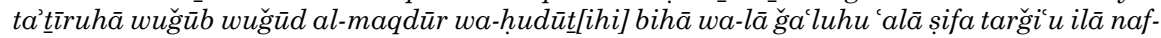
sihi wa-ğinsihi aw șifa tatba'u hudūtahu aw annahu kāin bihā 'alā ba'd haqà iqihi."

72 Al-Bāqillānī, Hidāya, MS St Petersburg, fol. 150b: "al-qudra innamā tatáallaqu bi-ihdāt ma'nā aw bi-iktisābihi bi-an tata'allaqa bihi wa-huwa mawğ $\bar{u} d$ aw bi-an yașīra bihā 'alā sifa tatba'u al-hudūt". 
for the question what precisely determines which of the possible alternatives will happen.

\section{CONCLUSION}

Mu'tazilite and Ašcarite theologians used to explain the link between human actions and moral responsibility in terms of man's capability or power (qudra). According to the Mu'tazilites, we are free agents by virtue of this very capability. It enables us to act otherwise than we do, but it in no way necessitates any action. Whether or not we act and whatever we do is completely up to us. Within the school, it was however debated whether our power over alternative acts is sufficient for us to control what we do, or whether our decision-making requires something else: some Mu'tazilites argued that exercising freedom depends on intentions or motivations in order to turn our abilities into real actions.

For al-Aš́arī, human acts that occur on account of man's power are voluntary acts. Man does not create his actions, but his acting is selfdetermined because he does things according to his willing and wanting. Yet it appears that al-Ašcarī believed that human capability or power has no effect whatsoever. This raised the question of the function of human power. It would seem that al-Bāqillānī attempted to solve the problem when he drew on al-Ašarı̀'s theory: where the latter speaks of mere conjunction between man's power and his act, al-Bāqillānī speaks of correlation. For him, human agents who are held responsible for what they do have a real property or attribute on account of their qudra. It is by virtue of this specific feature that they are distinguished from whoever is powerless (' $\bar{a} \breve{g} i z)$ and therefore irresponsible for actions he cannot refrain from performing. In addition, al-Bāqillānī suggests that man is related to his acts by virtue of his power, even though he does not create them. Consequently, man cannot be praised and blamed for the existence of his actions. Al-Bāqillānī therefore concludes that man assumes the responsibility for something else: he argues that God's command and prohibition relate to an attribute of acts that is caused by human power.

Acknowledgement: Early drafts of part II of this paper were presented at the workshop "Fresh Perspectives on Early Islamic Thought" at Göttingen University (March 2014); and the BRAIS conference (April 2014) in Edinburgh; I am grateful for the feedback I received on these occasions. I would like to thank Sabine Schmidtke for providing me with copies of the manuscripts of al-Bāqillānīs Hidāya, and two anonymous reviewers for their comments and suggestions. This research was supported by the Gerda Henkel Foundation's M4HUMAN programme. 